\title{
NURSE'S LEGAL COMPLIANCE ON HEALTH PROMOTION MANAGEMENT SYSTEM IN NURSING PRACTICES (A Study in Ajibarang Regional Public Hospital/RSUD in Banyumas Regency) ${ }^{\Omega}$
}

\author{
Saryono Hanadi \\ Law Faculty Universitas Jenderal Soedirman, Indonesia \\ E-mail: saryono.hanadi@unsoed.ac.id
}

\begin{abstract}
Recently, most nurses understad the standards and health promotion regulation yet only few implement them. This phenomenon is perceived disadvantageous habit which causes ineffective health promotion and poor health care to the community. Accordingly, this research will discuss the level of nurse's legal compliance on health promotion standard in nursing care and the influence of motivation and communication on the level of nurse's legal compliance for health promotion implementation in Ajibarang Hospital. This study applied sociological juridical research by using quantitative and qualitative methods. The results show, legal compliance to some extent is not independent or influenced by various factors. In this study, the non-legal factors that often affect the compliance of law include nurse motivation in implementing health promotion and nurse communication in performing health promotion.
\end{abstract}

Keywords: motivation factor, communication factor, legal compliance, nurse

\begin{abstract}
Abstrak
Dewasa ini banyak Perawat yang mengerti terhadap standar dan peraturan promosi kesehatan, namun tidak patuh dalam melaksanakannya. Fenomena ini dianggap oleh kalangan medis sebagai suatu kebiasaan yang pada akhirnya justru promosi kesehatan menjadi tidak efektif dan berakibat pada buruknya pelayanan kesehatan kepada masyarakat. Penelitian ini membahas tentang tingkat kepatuhan hukum Perawat terhadap standar promosi kesehatan dalam pelaksanaan asuhan keperawatan dan pengaruh faktor motivasi dan komunikasi terhadap tingkat kepatuhan hukum Perawat dalam pelaksanaan promosi kesehatan di Rumah Sakit Ajibarang. Penelitian ini menggunakan jenis penelitian yuridis sosiologis dengan menggunakan metode kuantitatif dan kualitatif. Berdasarkan hasil penelitian diketahui bahwa kepatuhan hukum dalam konteks tertentu tidaklah berdiri sendiri, akan tetapi cenderung dipengaruhi oleh berbagai faktor. Faktor-faktor non-hukum yang acap kali mempengaruhi terhadap kepatuhan hukum meliputi faktor motivasi Perawat dalam pelaksanaan promosi kesehatan dan faktor komunikasi Perawat dalam pelaksanaan promosi kesehatan.
\end{abstract}

Kata kunci : faktor motivasi, faktor komunikasi, kepatuhan hukum, perawat

\section{Introduction}

Since the International conference on population and development (LCPD) in 1994 at Kairo, a new paradigm in solving health issue emerged since traditional approach which was only based on physical and mental health is no longer applied, but by broader concept including reproductive and sexual health. ${ }^{1}$

$\Omega \quad$ This article is importat result from research funded by BLU Law Faculty Universitas Jenderal Soedirman in 2016
To realize best health care, the government issued Presidential Decree Number 72 Year 2012 on National Health System (SKN 2012). The function of SKN is believed effective to answer the problem of integrated health system with health funding sub-system, human resources sub-system, community empowerment sub-sys-

Anny Retnowati, "Politik Hukum dalam Menata Rekam Medis sebagai Sarana Perlindungan Hukum terhadap Rumah Sakit, Dokter dan Pasien", Yustisia, Vol. 2 No.2, May-August 2013, p. 144. 
tem, drug supply and pharmaceutical provision sub-sector, and health management sub-sector. As a major part of SKN, the healthcare system is divided into 2 (two) aspects of service: first, the sub-system of public health service with health service approach mainly concerns with health promotion and disease prevention programs; and second, individual healthcare or medical health services sub-systems focuses on curative and rehabilitative action. In this context, SKN creates a synergistic relationship among doctors, hospitals and patients as the three related subjects in the system of maintenance and health services to realize optimum health. They create both medical and legal relationships. ${ }^{2}$

To materialize SKN through a sustainable health service function, eligible health workers are required. As part of health workers, nurse functions to apply nursing service in health care facilities (fasyankes) in stages. Ideally, nursing services have standardized nursing practice as guidelines in performing nursing care activities in terms of nursing intervention. The interventions include nursing intervention, education and health counseling.

In line with the development of nursing science, the focus of nursing development on health promotion does not only concern with the process of public awareness in terms of giving and increasing health knowledge for society, but also an effort to provide change for one's behavior in keeping and maintaining health. Accordingly, health promotion is defined as one of the basic health services that must be held by health care facilities such as hospitals and health centers throughout nation. It is regulated in Article 3 of Law Number 29 Year 2009 on Health stating that "Health development aims to increase awareness, willingness and ability to live healthy for everyone in order to realize the highest degree of public health, as an investment for the development of human resources which are socially and economically productive". This means that the consolidation of the health system is intended to ensure the access of cost-

$2 \quad$ Anny Retnowaty, op.cit, p. 145. effective interventions for the development of public health. ${ }^{3}$

Practically, the implementation of health promotion often performed by nurses in some hospitals provides an unsatisfactory outcome. The success of a health promotion program depends on the performance of health promotion officers. So far, health promotion officers are only limited to health educators in charge of providing information. ${ }^{4}$

Basically, nurse's legal compliance on the standards and applicable regulations in carrying out health promotion is nurse's obligation in nursing practice. Legal compliance is essentially a law enforcer's loyalty on the standards and regulations materialized through real behavior patterns. The indicators of legal compliance involve; first, legal regulations knowledge; second, the legal regulations contents knowledge; third, attitudes toward legal regulations; and fourth, the pattern of legal behavior. ${ }^{5}$ Based on the statement above, therefore it is affirmed that: first, a good healing effort will not be realized unless supported by good service; and second, the criteria of good service are not sufficiently identified by experts involvement. Rather, it must be based on a good medical service system and also from the health care facilities. It can be assumed then that Nurses' compliance on health promotion standard as a media for the dissemination of health matters is crucial although various factors often influence Nurse's compliance in health promotion.

This condition makes the hospital service quality becomes one of the important factors to meet people right on health. In contrast, the hospital service quality is a unique phenomenondue to different dimensions and indicators among the people involved. In regard to this,

3 Tedi Sudrajat, Agus Mardiyanto, "Hak Atas Pelayanan dan Perlindungan Kesehatan Ibu dan Anak (Implementasi Kebijakan di Kabupaten Banyumas)", Jurnal Dinamika Hukum, Vol. 12 No.1, May 2012, p. 262.

4 Yuniarti, Zahroh Shaluhiyah; Bagoes Widjanarko, "Kinerja Petugas Penyuluh Kesehatan Masyarakat dalam Praktek Promosi Kesehatan di Dinas Kesehatan Kabupaten Pati”, Jurnal Promosi Kesehatan Indonesia, Vol. 7 No. 2, August 2012, p. 166.

5 M Husni, "Pemberdayaan Masyarakat sebagai Upaya Penegakan Hukum", Jurnal Equality, Vol. 11 No. 2, August 2006, p. 86 
basic guidelines for health services which is directed to perfect health service should be used to fulfill the needs and demands of health care users or patients. ${ }^{6}$ The research questions are formulated as follows: first, how is the level of Nurses' legal compliance on health promotion standard in the implementation of nursing practice?; and second, what is the influence of motivation and communication factors on Nurses' legal compliance level in the implementation of health promotion?

\section{Research Method}

This paper used a quantitative empirical legal research through a sociological-juridical approach. The approach aims to reveal the relationship between legal aspects and non-legal aspects. Legal aspect relates to the level of nurse's legal compliance and health promotion standard, while non-legal aspect concerns with suspected factors which have an effect on the level of Nurse's legal compliance like: first, nurse's motivation factor in Health Promotion implementation; and second, communication factor in Health Promotion process. It means that this approach methodologically recommends learning from people; it invites lawyers to study and research and provides legal meanings from the perspective of the users or justice seekers. ${ }^{7}$

The research took place in Ajibarang regional public hospital in Banyumas Regency with nurses who have status as permanent employee as the target of population. To determine the sample, this research used simple random sampling method based on preliminary research. It is known that there are approximately 120 nurses who served in RSUD Ajibarang in Banyumas regency. Out of those numbers, $50 \%$ was randomly taken as sample; therefore, the samples are 60 nurses. The processed data were presented in the form of tables, especially

Tri Rini Puji Lestari, "Pelayanan Rumah Sakit bagi Masyarakat Miskin (Studi Kasus di Enam Wilayah Indonesia)", KESMAS, Jurnal Kesehatan Masyarakat Nasional, Vol. 5 No. 1, August 2010, p. 9.

7 Zainab Ompu Jainah, "Membangun Budaya Hukum Masyarakat Penegak Hukum Dalam Pemberantasan Tindak Pidana Narkotika (Studi Tentang Lahirnya Badan Narkotika Nasional)", Keadilan Progresif, Vol. 2 No. 2, September 2011, p. 127. tables of frequency distribution and cross table and in the form of narrative text.

This research was analyzed by using quantitative and qualitative methods. Quantitative analysis is applied on quantitative data that emphasizes the use of simple statistical methods, especially the Frequency Distribution Analysis and Cross table Analysis. To support the analysis, this research uses data interpretation technique through theoritical interpretation method which focuses on discussion or dialog among data with legal theory, legal norm and legal doctrine.

\section{Discussion}

Nurse's Legal Compliance on Health Promotion Standard of Regional Public Hospital Ajibarang Banyumas

Law has a noble purpose to shape society in legal order. The ultimate presupposition regarding the importance of legal consciousness is that human are inadequate creatures. ${ }^{8}$ Therefore, legal awareness is required to grow legal compliance among people.

According to Soerjono Soekanto, legal compliance is obedience upon what is ordered and prohibited by the provisions of legislation for good expectation. ${ }^{9}$ Furthermore, law and social system is a unity in which the law exists since the people's will and the purpose of the formation of the law is for society. In other words, the law can only be comprehended by understanding the social system in advance that law is a process and legal system is a reflection of social system as a separated part.

If the issue of nurse's legal compliance on health promotion standard is interpreted based on the doctrine above, nurse's legal compliance is basically the nurse normative obligation in health promotion practice as an integrated part of nursing care which is manifested through "loyal behavior" and "obedience". This legal obligetion is stated in the provisions of Article 169 of

8 Wenda Hartanto, "Kesadaran Hukum Sebagai Aspek Dasar Politik Hukum Suatu Tatanan Filsafat", Rechsvinding Media Pembinaan Hukum Nasional, Vol. 4 No. 3, December 2015, p. 470

9 Soerjono Soekanto, 1982, Kesadaran Hukum dan Kepatuhan Hukum, Jakarta: Rajawali, p. 84. 
Law Number 36 Year 2009 on Health stating "the Government provides convenience to the public to gain access to health information as an effort to improve public health status". The nurse's legal obligations embodied in the form of "Loyal Behavior" and "Obedience" to the rule of law are also written in the provisions of Article 6 of Law Number 44 Year 2009 on Hospitals stating "the Government and Local Government are responsible for providing health information needed by the community". In addition, Law Number 29 Year 2004 on Medical Practice explains: first, providing protection to patients; second, maintaining and improving the quality of medical services provided by doctors and dentists; and third, providing legal certainty to the public, doctors and dentists. ${ }^{10}$

In relation to legal compliance, Kelman quoted by Soerjono Soekanto stated that compliance as a degree qualitatively can be distinguished in 3 (three) processes: firstly, compliance, defined as a compliance based on the expectation of a reward and effort to escape from possible penalty; secondly, identification is interpreted as obedience to the rules of law not for its intrinsic value but the group membership maintenance and establishment of good relationship with the authorized to apply the rules of law; and thirdly, internalization implies that a person obeys the rules of law for a reward. The contents of these rules are in accordance with their values from the beginning of the influence occurred, or because they changed the values they originally embraced. ${ }^{11}$

If management of health promotion standard in nursing practice is viewed from the loyal behavior and obedience of nurse aspect as a form of nurse's legal compliance, the results show that most nurses have high level of legal compliance on health promotion standard implementation. A clearer illustration is provided in the table below:

10 Hargianti Dini Iswandari, “Aspek Hukum Penyelenggaraan Praktik Kedokteran; Suatu Tinjauan Berdasarkan Undang-Undang No. 29/2004 tentang Praktik Kedokteran", Jurnal Manajemen Pelayanan Kesehatan, Vol. 09 No. 02 June 2006, p. 53.

11 Soerjono Soekanto, op.cit, p. 15
Table 1. The Level of Nurse's Legal Compliance on Health Promotions Standard

\begin{tabular}{l|l|c|c}
\hline Interval & Category & $\begin{array}{l}\text { Frequency } \\
(\mathrm{F})\end{array}$ & $\begin{array}{l}\text { Percentage } \\
(\%)\end{array}$ \\
\hline $47-59$ & Low & 9 & 15,00 \\
\hline $60-72$ & Hight & 19 & 31,67 \\
\hline $73-85$ & Medium & 32 & 53,33 \\
\hline Total & 60 & 100,00 \\
\hline
\end{tabular}

From the table above, it can be seen among 60 nurses as respondents, $9(15.00 \%)$ respondents have low level of Nurse's legal compliance, 19 $(31.67 \%)$ respondents indicate medium level, and 32 (53.33\%) respondents show high level on the nursing process and standards of practice. Thus, a tentative conclusion can be drawn that most nurses have high level of legal compliance on the nursing process and standards of practice. This is affected by nurse's knowledge and understanding that Health Promotion practice is a legal obligation to implement.

If the facts are interpreted based on Theory of H.C. Kelman which stated that legal compliance can occur in 3 (three) processes, namely Compliance, Identification and Internalization, ${ }^{12}$ the relatively high level of nurse's law compliance is included in Compliance. This fact happens due to the rewards in terms of salary and allowances received monthly. In addition, the practice of health promotion conducted by nurses regularly by utilizing given facilities reflect "loyal behavior" to the Regional Public Hospital and "obedience" to the hospital director to avoid sanctions (penalties) imposed by the Hospital in case that they do not perform the task of Health Promotion which is very beneficial for Patient.

Viewed from Identification process, it can be interpreted that the practice of health promotion is a process of Nurse's legal compliance to the applicable legal provisions to secure their profession membership and maintain good relationship among nurses through their authority to implement the provisions of the Health Promotion, through prioritizing group interests in nursing practice. In addition, the high nurse's com-

12 Loc.cit 
pliance is not separated from the Internalization process, where the Nurse behaves faithfully and is obedient to health promotion provisions, due to compensation in terms of salary and allowances, as well as the provisions of health promotion law in accordance with the values of nursing practice, in terms of Nurse's "Code of Ethics". The contents of the provisions of the health promotion law mean that carrying out health promotion tasks for the Nurse is a legal obligation instructed by applicable law. The nurse's loyal and obedient behavior towards the provisions of health promotion law is essentially a nurse's belief in the purpose of the provisions of health promotion law and regardless of the values of Nursing Practice and the supervision of hospital management.

Related to the facts in table 1 , the high level of nurse discipline in carrying out health promotion also basically forms the Nurse's high level legal compliance. This implies that the higher the level of nurse disciplines in the health promotion, the higher the degree of legal compliance of the Nurse to the provisions of health promotion law. Thus, there is a synergetic relationship between the elements of discipline Nurses in carrying out health promotion and Nurse's legal compliance towards provisions of applicable health promotion law.

Influence of Motivation and Communication Factor on the Level of Nurse's legal compliance in Health Promotion Implementation

Legal Compliance is basically a part of legal implementation which is inseparable from the influence of non-legal factors. It implies that legal compliance in certain contexts is not independent, influenced by various factors. In this study, non-legal factors that often affect the legal compliance focuses on Nurse's motivation factors and Nurse's communication factors in health promotion implementation.

Regarding motivation factor, the result revealed that most nurses have high motivation in doing health promotion. This is proven by the following table:

Table 2. Motivation Level of Nurse in Doing Health Promotion

\begin{tabular}{|c|c|c|c|}
\hline $\begin{array}{c}\text { Interval } \\
\text { Value }\end{array}$ & Category & $\begin{array}{c}\text { Frequency } \\
(\mathrm{F})\end{array}$ & $\begin{array}{c}\text { Percent- } \\
\text { age }(\%)\end{array}$ \\
\hline $6-8$ & low & 14 & 23,33 \\
$9-11$ & medium & 19 & 31,67 \\
$12-14$ & high & 27 & 45,00 \\
\hline & Total & 60 & 100,00 \\
\hline
\end{tabular}

Source: processed primary data

The table explains that out 60 respondents, $14(23.33 \%)$ respondents have low motivation level in doing health promotion, 19 (31.67\%) respondents are in medium level, and $27(45.00 \%)$ respondents are in high motivation level. It can be sum up then most of the respondents have high motivation in performing health promotion.

If nurse motivation level in Health Promotion implementation correlates to level of nurse legal compliance in health promotion standards, there is a tendency that the influence of motivation factor to the level of legal compliance in performing health promotion revealed in the following table:

Table 3. Influences of Motivation Factor on the level of Nurse's Legal Compliance in Health Promotion Implementation

\begin{tabular}{|c|c|c|c|c|c|c|c|c|}
\hline \multirow{2}{*}{ Motivation compliance } & \multicolumn{2}{|c|}{ low } & \multicolumn{2}{|c|}{ medium } & \multicolumn{2}{|c|}{ high } & \multicolumn{2}{|c|}{ Total } \\
\hline & $\mathrm{F}$ & $\%$ & $\mathrm{~F}$ & $\%$ & $\mathrm{~F}$ & $\%$ & $\mathrm{~F}$ & $\%$ \\
\hline low & 6 & 10,00 & 3 & 5,00 & 0 & 0,00 & 9 & 15,00 \\
\hline b. medium & 5 & 8,33 & 12 & 20,00 & 2 & 3,33 & 19 & 31,67 \\
\hline c. high & 3 & 5,00 & 4 & 6,67 & 25 & 41,67 & 32 & 53,33 \\
\hline Total & 14 & 23,33 & 19 & 31,67 & 27 & 45,00 & 60 & 100,00 \\
\hline
\end{tabular}


If the data from table 3 are partially reviewed in each level, it shows that $6(10,00 \%)$ respondents in low level, $12(20,00 \%)$ respondents in medium level and $25(41,67 \%)$ respondents in high level. The fact above can be interpreted that nurse motivation factor tends to positively influence the level of nurse legal compliance in health promotion implementation. It means that the higher nurse motivation level, the higher the level of nurse legal compliance in implementation of health promotion.

Besides motivation factor, it is believed that communication affect their compliance. Communication becomes an important role in teamwork to achieve a goal. Related to nurse as actor in implementing health promotion, there are two types of communications namely internal and external.

Internally, nurse communication as health workers in hospital and government is based on institutional structures as regulated in Regional Regulation of Banyumas Number 2 Year 2011 on Change upon Regional Regulation of Banyumas Regency Number 27 Year 2009 on Organization and Regional Institution Working Procedure of Banyumas. The influence of internal communication brings the implication on health service quality in Ajibarang hospital. As an example, what happened in Yogyakarta where any authority of health service transactions is centralized and controlled in regional regulations, the health service quality (includes communication in each sectors) will be developed. ${ }^{13}$ The next is external communication. The communication between nurse and patient is important. The interaction provides information about the patient's condition and in the meantime the nurse can offer some solutions by certain strategies; thus, the patient is encouraged to solve the problem. If the patient accepts and practices the given information, then the patient behavior will be adaptive as the main result of nursing intervention.
Research result shows that most of nurses have high communication level. This can be proven from the following data on the table:

Table 4. The Level of Nurse Communication in Health Promotion Implementation

\begin{tabular}{c|c|c|c}
\hline $\begin{array}{c}\text { Interval } \\
\text { Value }\end{array}$ & Category & $\begin{array}{c}\text { Frequency } \\
(\mathrm{F})\end{array}$ & $\begin{array}{c}\text { Percentage } \\
(\%)\end{array}$ \\
\hline $6-8$ & low & 8 & 13,33 \\
$9-11$ & medium & 9 & 15,00 \\
$12-14$ & high & 43 & 71,67 \\
\hline & Total & 60 & 100,00 \\
\hline
\end{tabular}

Source: processed primary data

From the table above, it shows that out of 60 respondents, $8(13,33 \%)$ respondents have low level of communication in implementing health promotion, $9(15,00 \%)$ respondents are medium level and $43{ }^{*} 71,67 \%$ ) respondents are in high level. All in all, most respondents show high communication level in health promotion implementation either with nurses or patients.

The communication between nurse and patient is therapeutic communication which aims to develop patient's personality into positive or adaptive way and lead to patient's development such as: first, self-realization, selfacceptance and improving self-respect. Through therapeutic communication, positive changes in patient is expected; second, the ability to build intrapersonal relationship which is not superficial and inter-dependent. Through this communication, patient will learn to accept and be accepted; third, function and ability to meet the needs and also to achieve realistic goal is improved; and fourth, clear sense of personal identity and self-integrity improvement. The personal identity includes status, role and gender.

If the fact from table 4 is linked with the fact from table 2 above, then it can be obtained the tendency of influence of communication factor to nurse legal compliance. It is proven by the table below:

13 Mailinda Eka Yuniza, "Pengaturan Pelayanan Kesehatan di Kota Yogyakarta Setelah Penerapan Otonomi Luas", Jurnal Mimbar Hukum, Vol. 25 No. 3, October 2013, p. 284. 
Table 5. Influences of Communication Factor on Nurse Legal Compliance Level in Health Promotion Implementation

\begin{tabular}{|c|c|c|c|c|c|c|c|c|}
\hline \multirow[t]{2}{*}{ Communication Compliance } & \multicolumn{2}{|c|}{ low } & \multicolumn{2}{|c|}{ medium } & \multicolumn{2}{|c|}{ High } & \multicolumn{2}{|c|}{ Total } \\
\hline & $\mathrm{F}$ & $\%$ & $\mathrm{~F}$ & $\%$ & $\mathrm{~F}$ & $\%$ & $\mathrm{~F}$ & $\%$ \\
\hline - low & 6 & 10.00 & 1 & 1,67 & 2 & 3.33 & 9 & 15,00 \\
\hline - medium & 2 & 3,33 & 7 & 11,66 & 10 & 16,67 & 19 & 31,66 \\
\hline - high & 0 & 0,00 & 1 & 1,67 & 31 & 51,67 & 32 & 53,34 \\
\hline Total & 8 & 13,33 & 9 & 15,00 & 43 & 71,67 & 60 & 100,00 \\
\hline
\end{tabular}

Source: proccessed primary data

At each level, it indicates that in low level of communication, $6(10,00 \%)$ respondents also show low level in legal compliance in implementing health promotion, in medium level, 7 $(11,66 \%)$ respondents also show medium level in legal compliance and in high level, $31(51,67 \%)$ respondents also show high level of legal compliance in health promotion implementation.

It can be interpreted then that nurse's communication factor tends to influence positively the legal compliance in implementation of health promotion. It means the higher level of communication, the higher level of nurse legal compliance. Furthermore, communication factor has a positive influence on nurse's legal compliance in implementing health promotion; the high level of nurse's communication has a logical consequence on the legal compliance although some of them have low level of communication but they show high level of legal compliance.

Interpreted based on Miftah Toha's opinion, it is obtained that communication factor is a strategic media in establishing medical relationship between nurse and patient, in form of providing and accepting information of patient's disease and performed medical equipment. Communication is also a media to deliver medical ideas and medical treatment between nurse and patient which also intends to share the information and messages to influence the patient.

\section{Conclusion}

Based on the discussion above, it concludes that nurse's legal compliance on health promotion standard in nursing practice in Ajiba- rang hospitals is high. The motivation and communication factors tend to influence positively to the level of nurse's legal compliance in implementing health promotion. It shows that the higher quality of motivation and communication, the higher nurse's legal compliance in implementing health promotion will be.

\section{Suggestion}

Comunication factor between health promotion officers and between nurse with hospital Head is essential and it determines the success of health promotion implementation. Therefore, a sociable and integrated communication model to support health promotion is required. Finally, coordination among health promotion officers can be well-established and substantive information is delivered through health promotion which is acceptable by patients.

Legal regulations which regulate the health promotion implementation so far is limited to Nurse Ethic Codes in Nursing Practice; thus, government, particularly hospital, needs to implement regulation in line with health promotion implementation. Those regulations should be the operational basis for health promotion officers; therefore, health promotion earns strong juridical legitimation as well as providing legal protection for Health Promotion officers.

\section{References}

Fitriono, Riska Andi. Budi Setyanto. Rehnalemken Ginting. "Penegakan Hukum Malpraktik Melalui Pendekatan Mediasi Penal". Yustisia. Vol. 5 No. 1. January-April 2016. Pp. 87-93. DOI: 10.20961/yustisia.v5i1. 8724; 
Hartanto, Wenda. "Kesadaran Hukum Sebagai Aspek Dasar Politik Hukum Suatu Tatanan Filsafat". Rechsvinding Media Pembinaan Hukum Nasional. Vol. 4 No. 3. December 2015. Pp. 469-483;

Husni, M. "Pemberdayaan Masyarakat Sebagai Upaya Penegakan Hukum". Jurnal Equality. Vol. 11 No. 2. August 2006. Pp. 86-93;

Iswandari, Hargianti Dini. “Aspek Hukum Penyelenggaraan Praktik Kedokteran; Suatu Tinjauan Berdasarkan Undang-Undang No. 29/2004 tentang Praktik Kedokteran". Jurnal Manajemen Pelayanan Kesehatan. Vol. 09 No. 02. June 2006. Pp. 52-57;

Jainah, Zainab Ompu. "Membangun Budaya Hukum Masyarakat Penegak Hukum Dalam Pemberantasan Tindak Pidana Narkotika (Studi Tentang Lahirnya Badan Narkotika Nasional)". Keadilan Progresif. Vol. 2 No. 2. September 2011. Pp. 123-136;

Lestari, Tri Rini Puji. "Pelayanan Rumah Sakit bagi Masyarakat Miskin (Studi Kasus di Enam Wilayah Indonesia)". KESMAS. Jurnal Kesehatan Masyarakat Nasional. Vol. 5 No. 1. August 2010. Pp. 9-16. DOI: 10.21109/kesmas.v5i1.156;
Retnowati, Anny. "Politik Hukum Dalam Menata Rekam Medis Sebagai Sarana Perlindungan Hukum Terhadap Rumah Sakit. Dokter Dan Pasien". Yustisia. Vol. 2 No. 2. May-August 2013. Pp. 144-153 DOI: 10.20961/ yustisia.v2i2.10208;

Soekanto, Soerjono. 1982. Kesadaran Hukum dan Kepatuhan Hukum. Jakarta: Rajawali;

Sudrajat, Tedi and Agus Mardiyanto. "Hak Atas Pelayanan Dan Perlindungan Kesehatan Ibu Dan Anak (Implementasi Kebijakan Di Kabupaten Banyumas)". Jurnal Dinamika Hukum. Vol. 12 No.1. May 2012. Pp. 261269. DOI: 10.20884/1.jdh.2012.12.2.43;

Yuniarti. Zahroh Shaluhiyah and Bagoes Widjanarko. "Kinerja Petugas Penyuluh Kesehatan Masyarakat dalam Praktek Promosi Kesehatan di Dinas Kesehatan Kabupaten Pati". Jurnal Promosi Kesehatan Indonesia. Vol. 7 No. 2. August 2012. Pp. 165173 DOI: 10.14710/jpki.7.2.165-173;

Yuniza, Mailinda Eka. "Pengaturan Pelayanan Kesehatan Di Kota Yogyakarta Setelah Penerapan Otonomi Luas". Jurnal Mimbar Hukum. Vol. 25 No. 3. October 2013. Pp. 377-387. DOI: $10.22146 /$ jmh. 16078 